Bazyli DEGÓRSKI O.S.P.P.E.

(Roma, Angelicum)

\title{
NAJSTARSZE PRAWODAWSTWO KOŚCIOŁA ŁACIŃSKIEGO W BASENIE MORZA ŚRÓDZIEMNEGO DOTYCZĄCE MNICHÓW
}

Ziemie, które otaczają Morze Śródziemne, były sceną pierwszego, najstarszego przepowiadania Ewangelii, a potem wielkiego prześladowania chrześcijan ze strony pogańskich cesarzy rzymskich. Gdy wreszcie dzięki edyktowi Konstantyna Wielkiego chrześcijaństwo zaznało względnego pokoju, zaczęło pojawiać się nowe zjawisko, nowy ruch charyzmatyczny, który narodził się na Wschodzie - monastycyzm.

Wielce ciekawe jest cechujące ten rodzący się monastycyzm prawodawstwo, które Kościół wypracował dla tego ruchu. Niniejszy artykuł pragnie przyjrzeć się bliżej powyższym cechom charakterystycznym monastycyzmu pierwszych wieków, używając do tego schematu geograficzno-regionalnego. Prześledzimy najstarsze prawodawstwo kościelne, dotyczące monastycyzmu męskiego IV-VI wieku w basenie Morza Śródziemnego. W życiu bowiem mnichów ujawniły się oryginalne wartości ascetyczne oraz specyficzne cechy kulturowe, które miały silny wpływ na rozwój nie tylko monastycyzmu łacińskiego, lecz także na życie Kościoła powszechnego. Niniejszy artykuł analizuje wszystkie kanony owego okresu, dotyczące ascetów, wydane przez Kościoły łacińskiej Afryki północnej, Galii, Półwyspu Iberyjskiego i Italii.

Synody badanego przez nas okresu ukazują bardzo dobrze życie Kościoła, odzwierciedlają różne trudności i sytuacje (częstokroć trudne), które wpłynęły na promulgację tychże kanonów, dając nam w ten sposób cenny obraz zarówno historyczny, jak i teologiczno-duchowo-prawny. Obraz ten jest wyjątkowo ważny, by właściwie poznać najstarszy, rodzący się monastycyzm, gdyż ten tak cenny dla Kościoła ruch charyzmatyczno-duchowy pojawił się właśnie w owym czasie i w nim znalazł swe podwaliny prawne, które zapewniły mu bezpieczeństwo w zdążaniu do domu Ojca wraz i - co więcej! - na czele reszty ludu Bożego, dla którego monastycyzm stał się przewodnikiem charyzmatyczno-duchowym.

Badając prawa dotyczące monastycyzmu męskiego, postępować będziemy za porządkiem chronologicznym wydania tychże przepisów. Zajmiemy się najpierw prawodawstwem afrykańskim, a następnie - Galii i Półwyspu Iberyj- 
skiego. Nie wykluczymy także Italii, aczkolwiek prawa wydane na jej obszarach, a dotyczące monastycyzmu męskiego, są bardzo rzadkie. Dzięki badanym zagadnieniom, które weszły do przepisów wówczas obowiązujących i niekiedy różniących się w zależności od miejsca promulgowania danej normy prawnej, poznajemy problemy, zwyczaje i dynamizm rozwoju monastycyzmu.

Całe te dzieje najstarszego monastycyzmu łacińskiego w basenie Morza Śródziemnego należy także rozpatrywać w świetle ich bezcennej wagi dla owego okresu, który potrafił przyjąć owo zjawisko ascetyczne jako wielki dar iście proroczy i nieskażony, jeśli idzie o odczytanie Ewangelii i jej zbawczej novitas, a przeszczepiony dzięki niektórym łacińskim wspólnotom mniszym nawet na Wschód, skąd ruch ten wziął początek, jak miało to miejsce w przypadku Rufina z Akwilei, Melanii Starszej, Melanii Młodszej, Hieronima i jego uczennic.

\section{WYŁĄCZENIE MNICHÓW I ICH ŚWIĘCENIA}

1. W Afryce Łacińskiej. Na początku VI wieku pojawiają się w Afryce przepisy dotyczące wyjęcia mnichów spod jurysdykcji biskupów. Synod bowiem z Kartaginy, który odbył się w dniach 5-6 lutego 525 roku, zajął się sporem między opatem Piotrem a prymasem Bizaceny - Liberatem, który próbował wkraczać w wewnętrzne sprawy klasztoru, którym kierował wspomniany Piotr $^{1}$.

${ }^{1}$ Por. Concilium Carthaginense (dies secunda: 6 II 525), CCL 149, 273-274: „Et cum tradidisset, Redemptiolus notarius recitavit: data a Petro abbate et ab universa congregatione eius. Rogamus, beatissime et apostolica dignitate praedite, Christi venerande pontifex Bonifati episcope, et omnes sancti sacerdotes qui nunc adesse videmini, ut suggestionem nostram intente adverti praecipias. Diu ad strepitus publicos interrupta quiete pervenire noluimus, diu intra monasterii latebras solis fletibus occupari voluimus et amica paenitentibus studuimus servare silentia. Vicit modo verecundiam dolor ac privata necessitas generale propositum conturbavit. Ex quo enim desiderii paginam voluntaria devotione conscribentes, huic venerabili sedi libertatem monasterii nostri commisimus vindicandam. Nova subito, sanctissimi sacerdotes, adversum nos exsurrexit tempestas invidiae. Sanctus quippe Liberatus, episcopus primae sedis provinciae Bizacenae, congregationibus sacerdotum saepe collectis, in perniciem nostram multa et multipliciter machinatur, dum in nobis quasi quandam materiem suae adsumptionis inveniens, post audientiae praefixum diem, post pacificae disputationis facultatem datam atque concessam, monasterium nostrum gravi excommunicatione percutere voluisset. Absit enim ut percussisse dicamus, scientes nos sub vestro velamine constitutos nullis posse aculis quorumlibet consiliorum penetrabiles deseri. Succurrite igitur tandem aliquando et a nostris cervicibus iugum, quod neque nobis neque patribus nostris quisquam superponere aliquando temptavit, excutite. Nihil contra fidem neque contra bonos admisimus mores: quia, si discutiatur ratio, licet liberis quocumque voluerint pertinere; si consideretur auctoritas, nulla adversum nos antiquorum patrum definitio profertur; si quaerantur exempla, multos ante fecisse inreprehensibiliter docemus quidquid modo fecisse culpamur. Ceterum, quod a proprio subdiacono monasterium, sicut audivimus, dicunt esse fundatum, quid praeiudicat olim mortui persona viventibus? Quando, etiamsi condicionem clericatus alicui debuit, condicio cum persona defecit. An fortasse Dominus fuit aut sic congregationi fratrum praefuit ut aliquid sibi proprium vindicaret quem, coenobialis regulae non ignari, dispensationem tantummo- 
Synod ten był pierwszym zgromadzeniem kościelnym w łacińskojęzycznej Afryce Północnej po długiej przerwie, która trwała wiek czasu, a która była spowodowana najazdem Wandali. Synod został zwołany przez prymasa Bonifacego - biskupa Kartaginy - i uczestniczyło w nim około sześćdziesięciu biskupów przybyłych z Afryki Prokonsularnej, z obszarów Trypolisu, Numidii, Mauretanii. Zgromadzili się oni in secretario basilicae sancti martyris Agilei. Nie uczestniczyli w nim jednak biskupi Bizaceny. Synod zajął się głównie ważnością hierarchiczną poszczególnych prowincji kościelnych Afryki, a także sprawami dotyczącymi monastycyzmu².

Niestety, z powodu lenistwa czy niedbalstwa kopistów w aktach tegoż synodu nie znajdujemy postanowień dotyczących sporu opata Piotra z prymasem Bizaceny - Liberatem. Możemy je jednak wywnioskować z akt następnego synodu kartagińskiego z 536 r., który potwierdził postanowienia powzięte podczas poprzedniego zebrania biskupów w Kartaginie w 525 r., a które dotyczyły wyjęcia mnichów spod władzy miejscowych biskupów ${ }^{3}$.

Co się zaś tyczy naszego zagadnienia, synod postanawia, iż mnisi mają się cieszyć całkowitą niezależnością względem biskupów, którzy nie mają żadnej władzy, jeśli chodzi o wewnętrzne sprawy klasztoru. Do władzy biskupa należy jedynie święcenie mnichów dla posługi duszpasterskiej wewnątrz mniszej wspólnoty, względnie w kaplicach podległych klasztorowi ${ }^{4}$.

2. W Galii. Ten sam przepis pojawił się już wcześniej w Galii. Wydał go synod w Arles, który obradował w roku nam nieznanym, a który możemy

do dicimus habuisse. Nec ideo nos eum, quia subdiaconus, sed propterea quia monachus fuit, abbatem habuimus. Unde, etsi forsitan alicui episcopo aliquando subdiaconus, nobis tamen monachus fuit; nec nos heredes honoris ecclesiastici, quem eum habuisse nescimus, sed sanctissimae professionis extitimus. Proinde lacrimabiliter obsecramus, nihil novum fiat in nobis, quia nihil novum factum docetur a nobis. Illuc ne opprimeremur confugivimus, ubi solent etiam clerici, si se opprimi viderint, appellare. Cur per dies singulos inauditis minis ab spiritali intentione deponimur? Cur ecclesiae simplex prohibetur accessus? Cur etiam in ecclesiis positi inprudenter iubemur foras a sacerdotibus pelli? cur etiam hospitalitas, quam semper exhibuimus, denegatur? Timent salutare qui diligunt; mutos Dei servos viator occurrit; benedictionem nobis transeuntibus nemo dare, nemo audet accipere".

2 Odnośnie do tego synodu por. Ch. Munier, Cartagine. V. Concili, DPAC I 611; tenże, Cartagine. V. Concili, NDPAC I 879-891.

${ }^{3}$ Odnośnie do tego synodu por. Munier, Cartagine. V. Concili, DPAC I 611

${ }^{4}$ Por. Concilium Carthaginense (a. 536), CCL 149, 283: „Felix episcopus Zactarensis provinciae Numidiae dixit: de monasterio abbatis Petri, ubi nunc Fortunatus abba constitutus est, quaedam temporibus sancti Bonifatii episcopi in universali concilio nobis etiam presentibus acta sunt, inconvulsa permaneant. Cetera vero monasteria etiam libertatem plenissimam perfruantur, servatis limitibus conciliorum suorum in haec dumtaxat, ut quandocumque voluerint sibi clericos ordinare vel ad oratoria monasteriis dedicare, episcopus in cuius plebe vel civitate locus monasterii consistit, ipse huius muneris gratiam compleat. Salva libertate monachorum, nihil sibi eis praeter hanc ordinationem vindicans, neque ecclesiasticis eos condicionibus aut angariis subdens". 
umieścić w latach 449-461. Odnośnie do dokładnej daty tegoż synodu, nie możemy niczego ściślejszego powiedzieć, jak tylko to, iż zebrał się on za rządów biskupa Rawenniusza z Arles, który był następcą św. Hilarego, to znaczy: właśnie w latach $449-461^{5}$. Z akt tegoż synodu pozostały tylko dwa dokumenty: list zwołujący synod, który wysłał biskup Rawenniusz ${ }^{6}$, oraz końcowy dokument, który kładzie kres sporowi, jaki wybuchnął z jednej strony pomiędzy opatem Faustem i mnichami z Lerynu, a Teodorem - biskupem Fréjus z drugiej strony, na obszarze którego znajdował się ten klasztor?

Przepis tegoż synodu zgadza się $\mathrm{z}$ tradycyjnym sposobem postępowania i potwierdza, iż do władzy biskupa w stosunku do klasztoru należy jedynie wyświęcanie zakonników, udzielanie bierzmowania i dopuszczanie do wspólnoty kościelnej czy do wykonywania posług kościelnych duchownych uważanych za peregrini. Wszystko zaś inne, co dotyczy życia klasztoru, pozostaje we władzy opata ${ }^{8}$. Synod natomiast w Agde z dnia 10 września 506 r. postanawia, że decyzja o święceniu mnichów pozostaje w gestii ich opata ${ }^{9}$.

Wyjęcie jednak klasztorów spod władzy biskupów dotyczy tylko mnichów, a nie mniszek. Co więcej, synod z Arles z dnia 29 czerwca 554 r. zobowiązuje biskupa, by wprost opiekował się klasztorami żeńskimi własnej diecezji ${ }^{10}$.

${ }^{5}$ Por. Ch. Munier, Concilium Arelatense in causa Fausti, CCL 148, 131. A. Hamman (Ravennio di Arles, DPAC II 2973) umieszcza go jednak w roku 453. Odnośnie do tegoż synodu, por. też Ch. Munier, Arles. V. Concili, DPAC I 366-367; J. Limmer, Konzilien und Synoden im spätantiken Gallien von 314 bis 696 nach Christi Geburt, Teil 1: Chronologische Darstellung, Frankfurt am Main 2004, 124-126; Ch. Munier - G. Pilara, Arles. V. Concili, NDPAC I 538-540.

${ }^{6}$ Por. Exemplar Epistulae generalis quae ad episcopos invitandos in causa Insulae Lerinensis missa est, CCL 148, 132.

${ }^{7}$ Por. Institutio sanctorum episcoporum Ravenni, Austici, Nectarii... in causa Insulae Lerinensis, CCL 148, 133-134.

${ }^{8}$ Por. Concilium Arelatense in causa Fausti (a. 449-461), CCL 148, 133-134: „Quin potius collationem, utpote antiquus abba et episcopus, ei ut piam ac necessariam perpetuo exhiberet et solacia secutura, quae verbis dignabatur promittere, rebus ipsis in quo usus exigeret plenissime exhiberet, hoc tamen sibi tantummodo vindicaturus quod decessor suus sanctae memoriae Leontius episcopus vindicaverat, idest ut clerici atque altaris ministri a nullo nisi ab ipso vel cui ipse iniunxerit ordinentur, chrisma nonnisi ab ipso speretur, neophyti si fuerint ab ipso confirmentur, peregrini clerici absque ipsius praecepto in communionem vel ad ministerium non admittantur. Monasterii vero omnis laica multitudo ad curam abbatis pertineat, neque ex ea sibi episcopus quidquam vindicet aut aliquem ex illa clericum nisi abbate petente praesumat. Hoc enim et rationis et religionis plenum est ut clerici ad ordinationem episcopi debita subiectione respiciant, laica vero omnis congregatio ad solam ac liberam abbatis proprii quem sibi elegerit ordinationem dispositionem que pertineat, regula quae a fundatore ipsius monasterii dudum constituta est in omnibus custodita".

${ }^{9}$ Por. Concilium Agathense (10 IX 506), can. 27, CCL 148, 205: „Si necesse fuerit clericum de monachis ordinari, cum consensu et voluntate abbatis praesumat episcopus”.

${ }^{10}$ Por. Concilium Arelatense (29 VI 554), can. 5, CCL 148 A, 171-172: „Ut episcopi de puellarum monastheriis, quae in sua civitate constituta sunt, curam gerant nec abbatissae eius monasterii aliquid liceat contra regulam facere". 
Przepis ten jednak został spowodowany troską o dobra materialne Kościoła zagrożone niedbalstwem czy zachłannością duchownych.

Ten synod prowincjalny zgromadził pod przewodnictwem miejscowego metropolity dziesięciu biskupów. Wzięło w nim udział także czterech kapłanów, dwóch archidiakonów i dwóch diakonów, którzy byli delegatami dwóch innych biskupów ${ }^{11}$. Synod wydał siedem kanonów, z których trzeci odwołuje się do postanowień poprzednich synodów. Przepisy te dotyczą liturgii i tych duchownych, którzy trwonią dobra kościelne. Ten sam synod w Arles postanawia również, iż klasztory i zachowywanie w nich karności mają zależeć od biskupa, na którego obszarze się znajdują ${ }^{12}$. Jak się jednak wydaje, kanon ten nie zaprzecza wyjęciu mnichów spod władzy biskupa miejsca, lecz tylko uściśla, do jurysdykcji którego hierarchy należą poszczególne klasztory ${ }^{13}$.

3. Na Półwyspie Iberyjskim. Także synody hiszpańskie potwierdzają niezależność klasztorów od władzy biskupów. Czyni to w 546 r. synod prowincjalny w Lerydzie ${ }^{14}$. Niekiedy synod ten umieszczany bywa w roku $524^{15}$. Data ta jednak według P. de Luisa nie jest do przyjęcia ${ }^{16}$. Synodowi przewodniczył metropolita Sergiusz z Tarragony. Uczestniczyło w nim sześciu biskupów i jeden kapłan jako przedstawiciel jeszcze innego biskupa. Synod wydał szesnaście kanonów dyscyplinarnych, które dotyczyły moralności duchownych i świeckich ${ }^{17}$.

Na Półwyspie Iberyjskim znajdujemy także przepisy dotyczące święcenia mnichów. W dokumencie bowiem papieża św. Syrycjusza I (wysłanym po roku 385 do biskupa Tarragony - Himeriusza - w odpowiedzi na jego list przesłany

11 Odnośnie do tego synodu, por. L. Navarra, Merovingi (concili), DPAC II 2228; Limmer, Konzilien und Synoden im spätantiken Gallien, s. 250-252.

12 Por. Concilium Arelatense (29 VI 554), can. 2, CCL 148 A, 171: „Ut monastheria vel monacorum disciplina ad eum pertineant episcopum, in cuius sunt terretorio constituta".

${ }^{13}$ Por. np. Concilium Epaonense (15 IX 517), can. 19, CCL 148, 29: „Abbas si in culpa repperiatur aut fraude et innocentem se adserens ab episcopo suo accepere noluerit successorem, ad metropolitani iudicium deducatur"; Concilium Aurelianense (23 VI 533), can. 21, CCL 148 a, 102: „Abbates qui episcoporum praecepta dispiciunt, ad communionem nec penitus admittantur, nisi contumaciam suscepta humilitate deponant. Sane si qui post hanc diligentissimam sanctionem non observaverint, quae sunt superius conpraehensa, reos se divinitatis pariter et fraternitatis iuditio futuros esse cognuscant".

${ }^{14}$ Por. Concilium Ilardense (a. 546), can. 3, Mansi VIII 613: „De monachis vero id observari placuit, quod synodus Agathensis, vel Aurelianensis noscitur decrevisse: hoc tantummodo adiciendum, ut pro Ecclesiae utilitate, quos episcopus probaverit in clericatus officio, cum abbatis voluntate debeant ordinari. Ea vero quae in iure monasterii de facultatibus offeruntur, in nullo dioecesana lege ab episcopis contingantur".

15 Por. np. Mansi VIII 609-610: „Concilium Ilardense, a. 524, octo episcoporum, habitum anno xv. Theodorici regis. viii. Idus Augusti, tempore Ioannis Papae”.

${ }^{16}$ Por. P. de Luis, Lérida, DPAC II 1935.

${ }^{17}$ Por. tamże. 
ok. 384 r. papieżowi św. Damazemu, w którym to liście pytał papieża o zdanie w różnych kwestiach dyscyplinarnych) jeszcze raz mówi się, iż także mnisi, którzy na to zasługują, mogą zostać duchownymi. Papież określa ponadto wiek osób mogących przyjąć święcenia i podkreśla wagę i konieczność zachowania odpowiednio określonych odstępów czasowych pomiędzy udzielaniem poszczególnych święceńn ${ }^{18}$.

Należy także powiedzieć, iż papież Syrycjusz I podkreśla wagę jurydyczną sukcesji Piotrowej, rolę sedes apostolica dla zachowania czystości wiary, oraz wspomina o symbiozie polityki kościelnej z cesarską, a na koniec mówi o poszerzeniu władzy papieskiej na Wschodzie poprzez ustanowienie wikariatu w Tesalonikach ${ }^{19}$.

\section{STAŁOŚĆ MIEJSCA MNICHÓW}

1. W Afryce Łacińskiej. Pierwsze przepisy dotyczące stałości miejsca mnichów, czyli dotyczące zakazu opuszczania klasztoru bez pozwolenia opata, znajdujemy w postanowieniach synodów afrykańskich.

Synod z Kartaginy z dnia 13 września 401 r. ustala bowiem, iż nie wolno żadnemu biskupowi przyjąć w poczet duchowieństwa swej diecezji mnicha, który pochodzi spoza jego jurysdykcji. Nie wolno mu także ustanawiać go przełożonym w którymś z klasztorów znajdujących się na obszarze jego diecezji. Gdyby to uczynił, grozi mu kara zerwania komunii z innymi biskupami (nie jednak z własnymi diecezjanami). Mnich natomiast, który by został przyjęty przez takiego biskupa, ma zostać złożony z urzędu ${ }^{20}$. Ten sam przepis spoty-

18 Por. Siricius I, Epistula ad Himerium Tarraconensem (post a. 385), Mansi III 660: „Monachos quoque, quos tamen morum gravitas, et vitae ac fidei institutio sancta commendat, clericorum officiis aggregari et optamus et volumus, ita ut qui intra tricesimum aetatis annum sunt digni, in minoribus per gradus singulos, crescente tempore, promoveantur ordinibus: et sic ad diaconatus vel presbyterii insignia, maturae aetatis consecratione perveniant. Nec statim saltu ad episcopatus culmen ascendat, nisi in his eadem, quae singulis dignitatibus superius praefiximus, tempora fuerint custodita".

19 Por. J. Woch, „Portamus onera omnium qui gravantur [...]”. Il pontificato di Papa Siricio (384-399) alla luce dei suoi scritti e delle fonti archeologiche [= Excerpta ex dissertatione ad Doctoratum in Theologia et Scientiis Patristicis, Institutum Patristicum „Augustinianum”], Romae 2001, 81-106.

${ }^{20}$ Por. Registri Ecclesiae Carthaginensis excerpta. Concilium Carthaginense (13 IX 401), can. 80, CCL 149, 204: „Item placuit ut si quis de alterius monasterio repertum vel ad clericatum vel in suo monasterio maiorem monasterii constituerit episcopus, qui hoc fecerit, a communione seiunctus, suae tantum plebis communione contentus sit; et ille neque clericus neque praepositus perseveret". Co się tyczy tego kanonu, por. także B. Degórski, Kler afrykański w świetle synodów IV i V wieku, VoxP 6 (1986) z. 10, 229; tenże, Peculiarità nel monachesimo del Mediterraneo latino secondo $i$ concili dei secoli IV-VI, w: Cristianesimo e specificità regionali nel Mediterraneo latino sec. IV-VI (XXII Incontro di studiosi dell'antichità cristiana, Roma, 6-8 maggio 1993, Istituto Patristico „Augustinianum”, SEA 46, Roma 1994, 109. 
kamy aż dwa razy w tzw. Collectio Hispana synodów afrykańskich (z czego jeden raz ad litteram), oraz w zbiorze dokumentów prawnych, którego dokonał kartagiński diakon - Ferrand ${ }^{21}$.

Wspomniany synod kartagiński odbył się pod przewodnictwem biskupa Kartaginy - św. Aureliusza. Zebrał się on przede wszystkim po to, by przywrócić jedność kościelną zachwianą przez schizmę donatystów. Synod ten ogłosił wiele kanonów dyscyplinarnych dotyczących czystości i rezydencji duchownych, postępowania biskupów i chrztu dzieci ${ }^{22}$.

2. W Galii. Pierwszy przepis Kościoła Galii, który odnosi się do stałości miejsca pobytu mnichów, wydał 4 października 453 r. synod w Angers. Odbył się on pod przewodnictwem Eustochiusza - biskupa Tours - i zgromadził siedmiu biskupów, którzy przybyli do Angers, aby wyświęcić biskupa Talasjusza. Synod ten wydał dwanaście kanonów dyscyplinarnych, które dotyczyły z zasady obowiązków duchownych ${ }^{23}$.

Co się tyczy prawodawstwa monastycznego, synod w Angers ustalił, że wałęsający się mnisi mają być wyklęci i nie mogą zostać przyjęci ani przez swych opatów, ani przez żadnego biskupa ${ }^{24}$. Prawo to, które odzwierciedla czwarty kanon soboru powszechnego w Chalcedonie z $451 \mathrm{r}^{25}$, przejmie i poszerzy synod w Vannes, który zgromadził się w roku dla nas nieznanym, a który jednak możemy umieścić w latach 461-491. W postanowieniach tego synodu

${ }^{21}$ Por. Concilium Carthaginense quintum, can. 13, CCL 149, 358: „Item placuit ut si quis de alterius monasterio repertum vel ad clericatum promovere voluerit vel in suo monasterio maiorem monasterii constituere, episcopus qui hoc fecerit, a ceterorum communione seiunctus, suae tantum plebis communione contentus sit, et ille neque clericus neque praepositus perseveret"; Concilia Africana secundum traditionem collectionis quae Hispana nuncupatur. Sylloge Africanorvm conciliorum in epitome Hispanica, can. 39, CCL 149, 315: „Clericum vel monachum alienum non liceat accipere”; Ferrandvs Carthaginensis, Breviatio canonum (a. 523-546), can. 27, CCL 149, 289: „Ut nullus episcopus alienum monachum vel in Ecclesia ordinet vel in monasterio suo praepositum faciat Concilio Carthaginensi, tit. 14".

22 Odnośnie do tego synodu por. Munier, Cartagine. V. Concili, DPAC I 605-606.

23 Odnośnie do tego synodu, por. Ch. Munier, Angers (concilio di), DPAC I 203; Limmer, Konzilien und Synoden im spätantiken Gallien, s. 126-130; Ch. Munier, Angers (concilio di), NDPAC I 301.

${ }^{24}$ Por. Concilium Andegavense (4 X 453), can. 8, CCL 148, 138: „Monachi quoque qui coeptam observationis viam relinquunt et absque epistolis et absque certis negotiis vel necessitatibus per regiones vagantur alienas cognita districtione si se non emendaverint, ab abbatibus suis vel a sacerdotibus ad communionem non recipiantur".

${ }^{25}$ Wyraźnie wspomina Sobór Chalcedoński (451) synod z Barcelony, który zebrał się w 540 r. pod przewodnictwem metropolity Sergiusza z Tarragony. Wzięło w nim udział sześciu biskupów. Synod ten wydał dziesięć kanonów dotyczących liturgii, duchowieństwa i chorych. Co się tyczy mnichów, synod ten nakazuje im zachowywanie wszystkich praw, które w tym względzie wydał sobór w Chalcedonie, por. Concilium Barcinonense (a. 540), can. 10, Mansi IX 110: „De monachis vero id observari praecipimus, quae synodus Chalcedonensis constituit". Odnośnie do tego synodu, por. De Luis, Barcellona, DPAC I 475-476. 
czytamy, że wałęsający się mnich, jeśli się nie poprawi pod wpływem perswazji, ma być zmuszony do powrotu do klasztoru za pomocą bicza ${ }^{26}$. Jest to, jak się wydaje, jedyne prawo w łacińskim basenie Morza Śródziemnego w owym czasie, które przewiduję karę cielesną dla ascetów. Przepis ten przejmie dosłownie synod w Adge, który odbył się dnia 10 września 506 roku $^{27}$. Synod ten ponadto postanowił, że wałęsający się mnisi nie mogą zostać wyświęceni bez pozwolenia ich opata. Bez takiego pozwolenia nie może ich także przyjąć żaden opat. Mnisi wałęsający się mieli powrócić do swoich klasztorów ${ }^{28}$.

Dalszego poszerzenia tych przepisów dokonał synod w Orleanie z dnia 10 lipca 511 roku. Postanowił on bowiem, iż sam biskup musi zabiegać, aby wałęsający się mnich wrócił do swego klasztoru. Synod postanawia także, iż popełnia przestępstwo zarówno opat, który niczego w tej sprawie nie robi, jak i ten, który przyjmuje wałęsającego się mnicha ${ }^{29}$. Prawo to zostało w sposób skrótowy potwierdzone przez synod w Tours z dnia 18 listopada 567 roku $^{30}$.

3. Na Półwyspie Iberyjskim. Na Półwyspie Iberyjskim spotykamy tylko jeden kanon, który zajmuje się rozważanym tu przez nas zagadnieniem. Wydał go w 516 r. synod w Tarragonie. Temu synodowi prowincjalnemu przewodniczył metropolita Jan, a uczestniczyło w nim siedmiu biskupów z tejże metropolii, oraz metropolita Kartageny i biskup Elwiry. Synod wydał trzynaście kanonów dyscyplinarnych, które zajmują się postępowaniem duchownych i mnichów ${ }^{31}$.

Co się tyczy naszego zagadnienia, synod w Tarragonie postanawia, iż wałęsający się mnich bez pozwolenia swego opata nie może spełniać żadnej po-

${ }^{26}$ Por. Concilium Veneticum (a. 461-491), can. 6, CCL 148, 153: „In monachis quoque par sententiae forma servetur [por. tamże, can. 5: „Clericis sine commendaticiis epistolis episcopi sui licentia non pateat evagandi, et in omni loco ad quem sine epistolis episcopi sui, ut dictum est, venerint, a communione habeantur alieni", CCL 148, 152]; quos si verborum increpatio non emendaverit, etiam verberibus statuimus coerceri".

27 Por. Concilium Agathense (10 IX 506), can. 38, CCL 148, 208-209: „Clericis sine commendaticiis epistolis episcopi sui licentia non pateat evagandi. In monachis quoque par sententiae forma servetur; quos si verborum increpatio non emendaverit, etiam verberibus statuimus coerceri".

28 Por. Concilium Agathense (10 IX 506), can. 27, CCL 148, 205: ,[...]. Monachi etiam vagantes ad officium clericatus, nisi eis testimonium abbas suus dederit, nec in civitatibus nec in parrociis ordinentur. Monachum nisi abbatis sui aut permissu aut voluntate ad alterum monasterium commigrantem nullus abbas suscipere aut retinere praesumat, sed ubicumque fuerit, abbati suo auctoritate canonum revocetur".

29 Por. Concilium Aurelianense (10 VII 511), can. 19, CCL 148 A, 10: „[...]. Ipsi autem qui fuerint pervagati, ubi inventi fuerint, cum auxilio episcopi tanquam fugacis sub custodia revocentur; et reum se ille abba futurum esse cognoscat, qui in huiusmudi personas non regulari animadversione distrinxerit vel qui monachum susceperit alienum".

${ }^{30}$ Por. Concilium Turonense (18 XI 567), can. 16 (15), CCL 148 A, 181: ,,Si qui in monasterio conversi sunt aut converti voluerint, nullatenus exinde habeant licentiam evagandi nec, quod absit, ullus eorum coniugem ducere aut extranearum mulierum familiaritatem habere".

31 Odnośnie do tego synodu, por. P. de Luis, Tarragona. II. Concili, DPAC II 3347. 
sługi duszpasterskiej, czy nawet wykonywać jakiejkolwiek działalności świec$\mathrm{kiej}^{32}$. Synod ten nie zajmuje się więcej tym zagadnieniem, lecz odsyła w tej sprawie do wcześniejszych kanonów galijskich.

\section{POKORA, POSTY I LITURGIA MNICHÓW}

Istnieje niewiele kanonów odnośnie do sposobu zachowania się mnichów w klasztorze ze szczególnym uwzględnieniem wypełniania cnoty pokory, umartwienia, czy sposobu modlenia się.

1. W Galii. Synod w Orleanie z dnia 10 lipca 511 r. postanawia, że mnisi nie powinni ubierać stuły oraz nosić wysadzanych drogimi kamieniami pierścieni ${ }^{33}$, powinni natomiast być posłuszni i całkowicie poddani swoim opatom ${ }^{34}$.

Na temat postów i liturgii mniszej wypowiedział się synod w Tours z dnia 18 listopada 567 roku. Potwierdził on antiqua instituta i ustalił szczegółowy rozkład mniszych postów: od Wielkanocy do Zesłania Ducha Świętego mnisi mają jeść normalnie każdego dnia (za wyjątkiem tzw. rogationes), a zachowywać post począwszy od tygodnia po Zesłaniu Ducha Świętego. Co się tyczy owych rogationes, należy powiedzieć, iż może chodzi tu o litaniae minores, które pojawiły się po raz pierwszy w Vienne w Galii, a które odprawiano przez trzy dni poprzedzające Wniebowstąpienie Pańskie. Nie chodzi tu chyba o owe litaniae maiores, które odprawiano dnia 25 kwietnia, a które pojawiły się w Rzymie w VI wieku, zastępując pogańskie „robigalia” odprawiane na cześć numen mszycy zboża - Robigusa. Sprawowano je przy piątym kamieniu milowym Via Claudia. Podczas tego święta kapłan (Flamen Quirinalis) składał w ofierze psa i owcę, modląc się, by mszyca nie dotknęła zboża $^{35}$.

${ }^{32}$ Por. Concilium Tarraconense (a. 516), can. 11, Mansi VIII 543: „Monachis a monasterio foras egredientes, ne aliquid ministerium ecclesiasticum praesumant agere prohibemus, nisi forte cum abbatis imperio. Similiter, ut nullus eorum (id est monachorum) forensis negotii susceptor vel executor existat, nisi id quod monasterii exposcit utilitas: abbate sibi nihilo minus imperante, canonum ante omnia Gallicanorum de eis constitutione servata".

${ }^{33}$ Por. Concilium Aurelianense (10 VII 511), can. 20, CCL 148 A, 10: „Monacho uti orarium in monasterio vel cyanchas habere non liceat"; zob. także O. Pontal, Recherches sur le costume des clercs des origines au XIV siècle d'après les décrets des conciles et des synodes, „L'année canonique" 17 (1973) 769-796; taż, Die Synoden im Merowingerreich [= Konziliengeschichte], Paderborn - München - Wien - Zürich 1986, 32.

${ }^{34}$ Por. Concilium Aurelianense (10 VII 511), can. 19, CCL 148 A, 10: ,[...]. Monachi autem abbatibus omni se obedientiae devotione subiciant. Quod si quis per contomaciam exteterit indevotus aut per loca aliqua evagari aut peculiare aliquid habere praesumserit, omnia quae adquisierit, ab abbatebus auferantur secundum regulam monasterio profutura".

35 Por. Ch. Pietri, Gallia, DPAC II 1423; P. Fahey, Processione, DPAC II 2909. 
Co się tyczy innych postów, synod w Tours postanowił, że aż do końca miesiąca lipca mnisi powinni pościć trzy razy w tygodniu: w poniedziałek, środę i piątek; przepis ten jednak nie dotyczył chorych. W miesiącu zaś sierpniu zważywszy, iż każdego dnia czci się jakiegoś świętego - mnisi mogą jeść normalnie. Od początku września do końca listopada zakonnicy powinni znowu pościć trzy razy w tygodniu. Od początku grudnia do Bożego Narodzenia mają pościć każdego dnia. Od Bożego Narodzenia do Objawienia Pańskiego mnisi będą jeść normalnie. Wyjątek tu będą stanowiły trzy dni poprzedzające 1 stycznia, podczas których odprawia się litanie ad calcandam gentilium consuetudinem. Podczas tego triduum zakonnicy mają śpiewać psalmy w kościele, a dnia 1 stycznia odprawić Mszę Świętą z okazji Obrzezania Pańskiego. Od Objawienia Pańskiego aż do Wielkiego Postu zakonnicy znów mają pościć trzy razy w tygodniu ${ }^{36}$.

2. Na Półwyspie Iberyjskim. Dzięki postanowieniom II synodu w Bradze z dnia 1 maja 561 r. wiemy, że liturgia monastyczna różniła się od tej, którą odprawiali duchowni diecezjalni. Chcąc bowiem zwalczyć pryscylianizm, który często znajdował ostoję wśród mnichów, gdyż także on jawił się jako pobożny ruch charyzmatyczny, synod ten postanowił ujednolicić sprawowanie godzin kanonicznych i zakazał w tym względzie podtrzymywania jakichkolwiek zwyczajów mniszych ${ }^{37}$.

\section{PRAWOWIERNOŚĆ MNICHÓW}

1. W Galii. Synod w Orleanie z dnia 10 lipca 511 r., troszcząc się o zachowanie prawowiernej nauki wśród kleru, zabronił duchownym oraz mnichom wierzenia we wróżby i ich praktykowania. W szczególności synod wspomina

${ }^{36}$ Por. Concilium Turonense (18 XI 567), can. 18 (17), CCL 148 A, 182: „De ieiuniis vero antiqua a monachis instituta conserventur, ut de pascha usque quinquagessima excepto rogationes omne die fratribus prandium praeparetur; post quinquagessima tota ebdomada ex asse ieiunent. Postea usque kalendas Augusti ter septimana ieiunent: secunda, quarta et sexta die excepto his, qui aliqua infirmitate constricti sunt. Augusto, quia cotidie missae sanctorum sunt, prandium habeant; Septembro toto et Octobro et Novembro, sicut prius dictum est, ter in septimana, de Decembre usque natale Domini omni die ieiunent. Et quia inter natale Domini et epyfania omni die festivitates sunt, idemque prandebunt excepto triduum illud, quod ad calcandam gentilium consuetudinem patris nostri statuerunt, priuatas in kalendis Ianuarii fieri letanias, ut in ecclesia psalletur et ora octava in ipsis kalendis circumcissionis missa Deo propitio celebretur; post epyfania vero usque quadragensima ter in septimana ieiunent"; zob. także Limmer, Konzilien und Synoden im spätantiken Gallien, s. 452, przypis 1653.

37 Por. Concilium Bracarense secundum (1 V 561), cap. 1, Mansi IX 777: „Placuit omnibus communi consensu, ut unus atque idem psallendi ordo in matutinis vel vespertinis officiis teneatur; et non diversae, ac privatae, neque monasteriorum consuetudines cum ecclesiastica regula sint permixtae". 
i zakazuje wróżb losowych, quas mentiuntur esse sanctorum. Owe sortes sanctorum polegały na przypadkowym otwarciu Pisma Świętego, czy jakiegoś dzieła patrystycznego, i przekonaniu, że napotkany w ten sposób tekst daje odpowiedź na zadane pytanie ${ }^{38}$. Synod grozi nawet ekskomuniką osobom, które nie przestrzegają tego zakazującego prawa ${ }^{39}$.

2. Na Półwyspie Iberyjskim. Prawa Kościoła na Półwyspie Iberyjskim, dotyczące prawowierności mnichów, wydawano przede wszystkim po to, by zwalczać pryscylianizm. Pierwszy synod w Saragossie z 380 r. zabrania duchownym zostawania mnichami pod wpływem pobudek pryscyliańskich. Ci, którzy przekraczają ten przepis, mają być wyklęci i będą mogli powrócić do Kościoła jedynie po odbyciu długiej pokuty ${ }^{40}$. W podobnym duchu wypowiada się synod z Bragi z 561 r., który zakazuje mieszkania zakonników z obcymi kobietami, co było dozwolone w sekcie pryscylian ${ }^{41}$.

\section{OPACI}

1. W Galii. Prawodawstwo dotyczące opatów jest stosunkowo obszerne na ziemiach Galii. Tu i ówdzie widzieliśmy już w naszych rozważaniach przepisy dotyczące opatów. Z tego względu przedstawimy tutaj jedynie te kanony, którymi jeszcze się nie zajmowaliśmy.

Synod w Vannes, który obradował w roku bliżej nam nieznanym, a który jednak musimy umieścić w latach 461-491, postanawia, iż opat może posiadać tylko jedną celę i kierować jednym klasztorem ${ }^{42}$. Przepis ten przejął dosłownie

${ }^{38}$ Por. F. Rocquain, Les sorts des saints ou des apôtres, „Bibliothèque de l'École des Chartres" 41 (1880) 457; C. de Clercq, CCL 148A, 12, przypis 30; Limmer, Konzilien und Synoden im spätantiken Gallien, s. 452, przypis 1154.

39 Por. Concilium Aurelianense (10 VII 511), can. 30, CCL 148 A, 12: „Si quis clericus, monachus, saecularis divinationem vel auguria credederit observanda vel sortes, quas mentiuntur esse sanctorum, quibuscumque potaverint intimandas, cum his, qui is credederint, ab ecclesiae conmunione pellantur"; zob także Concilium Veneticum (a. 461-491), can. 16.

${ }^{40}$ Por. Concilium Caesaraugvstanum primum (a. 380), can. 6, Mansi III 635: ,[...] Si quis de clericis propter luxum, vanitatemque praesumptam, de officio sponte discesserit, ac velut observatorem legis monachum videri voluerit esse magis quam clericum, ita de ecclesia repellendum, ut nisi rogando atque obsecrando plurimis temporibus satisfecerit, non recipiatur. Ab universis episcopis dictum est: Ita fiat".

${ }^{41}$ Por. Concilium Bracarense secundum (a. 561), can. 15, Mansi IX 776: „Si quis clericorum vel monachorum praeter matrem, aut germanam, vel thiam, vel proximam sibi consanguineam iunguntur, aliasque aliquas adoptivas feminas secum retinent, et cum ipsis cohabitant, sicut Priscilliani secta docuit, anathema sit".

42 Por. Concilium Veneticum (a. 461-491), can. 8, CCL 148, 153: „Abbatibus quoque singulis diversas cellas aut plura monasteria habere non liceat, nisi tantum propter incursum hostilitatis intra muros receptacula collocare". 
synod w Agde z dnia 10 września $506 \mathrm{r}^{43}$, podczas gdy synod w Épaone z dnia 15 września 517 r. przejął jedynie drugą część powyższego przepisu ${ }^{44}$. Opat jednak - zgodnie z synodem w Orleanie z dnia 10 lipca 511 r. - może upoważnić podległego mu mnicha do opuszczenia klasztoru i wybudowania sobie celi poza opactwem. Może się to jednak dokonać tylko za uprzednim pozwoleniem biskupa $^{45}$.

W omawianym przez nas okresie pojawiają się także pierwsze kary dotyczące opatów. Synod w Épaone ustala bowiem, iż - jeśli opat popełniłby jakieś przestępstwo, lecz, uważając się za niewinnego, nie chciałby poddać się karze złożenia z urzędu, zasądzonej mu przez biskupa - może odwołać się do sądu metropolity ${ }^{46}$.

Ważnym jest tu także synod w Orleanie z dnia 23 czerwca 533 roku. Niektórzy badacze umieszczają go w roku 536. Datę tę trzeba jednak odrzucić, gdyz - jak wiemy - synod ten zgromadził się w dwudziestym drugim roku panowania króla Childeberta, tzn. w 533 r., a przewodniczył mu Honorat z Bourges. W synodzie uczestniczyło pięciu metropolitów i jeden kapłan jako delegat innego metropolity, osiemnastu biskupów i dwóch kapłanów. Ci ostatni byli przedstawicielami sześciu prowincji kościelnych. W synodzie uczestniczyło ponadto trzech biskupów i dwóch kapłanów. Synod wydał dwadzieścia jeden kanonów dyscyplinarnych dotyczących duchowieństwa, małżeństw mieszanych chrześcijan z żydami (synod uznał te małżeństwa za nieprawne), oraz ekskomuniki katolików, którzy zapierają się, czy wyrzekają się wiary. Kanony 7 i 17 odwołują się do wcześniejszych praw ${ }^{47}$. Otóż ostatni kanon tegoż synodu grozi klątwą tym opatom, którzy gardzą nakazami biskupów. Aby odpokutować za takie postępowanie, opaci ci powinni upokorzyć się i poniechać uporu ${ }^{48}$. Drugi synod w Arles z dnia 29 czerwca 554 r. postanawia ponadto, że opat nie może

43 Por. Concilium Agathense (10 IX 506), can. 38, CCL 148, 209: ,Abbatibus quoque singulis diversas cellulas aut plura monasteria habere non liceat, nisi tantum propter incursum hostilitatis intra muros receptacula collocare".

44 Por. Concilium Epaonense (15 IX 517), can. 9, CCL 148 A, 26: „Unum abbatem duobus monasteriis interdicemus praesedere".

45 Por. Concilium Aurelianense (10 VII 511), can. 22, CCL 148 A, 11: „Nullus monachus congregatione monasterii derelicta ambitionis et vanitatis inpulso cella construere sene episcopi permissione vel abbatis sui voluntate praesumat".

${ }^{46}$ Por. Concilium Epaonense (15 IX 517), can. 19, CCL 148 A, 29: „Abbas si in culpa repperiatur aut fraude et innocentem se adserens ab episcopo suo accepere noluerit successorem, ad metropolitani iudicium deducatur".

47 Odnośnie do tego synodu, por. Navarra, Merovingi (concili), DPAC II 2228; Limmer, Konzilien und Synoden im spätantiken Gallien, s. 208-212.

48 Por. Concilium Aurelianense (23 VI 533), can. 21, CCL 148 A, 102: „Abbates qui episcoporum praecepta dispiciunt, ad communionem nec penitus admittantur, nisi contumaciam suscepta humilitate deponant. Sane si qui post hanc diligentissimam sanctionem non observaverint, quae sunt superius conpraehensa, reos se divinitatis pariter et fraternitatis iuditio futuros esse cognuscant". 
opuszczać klasztoru bez pozwolenia biskupa. W przeciwnym razie - zgodnie z przepisami „starożytnych kanonów” - biskup będzie go musiał skarcić ${ }^{49}$.

W obronie opatów staje jednak synod w Tours z dnia 18 listopada 567 r., uściślając, iż biskup musi zaciągnąć rady wszystkich swych kapłanów i innych opatów, aby móc interweniować względem jakiegoś opata, czy podjąć w jego sprawie jakieś ważne postanowienie ${ }^{50}$. Jak ma to miejsce w przypadku duchownych diecezjalnych, także opaci nie mogą alienować, czy wpisywać na hipotekę dóbr kościelnych bez pisemnego pozwolenia biskupa. Tak postanawia synod w Orleanie z dnia 7 maja 538 roku. Winni tego przestępstwa mają być pozbawieni komunii, a sam akt alienacji czy hipoteki biskup ma prawo unieważnić ${ }^{51}$.

Synod w Orleanie dnia 10 lipca 511 r. zobowiązuje także opatów do udawania się raz w roku na jakieś ustalone przez biskupa miejsce. Mogłoby się wydawać, iż chodzi tu o synod diecezjalny, chociaż nawet kanon mówi wprost tylko o gromadzeniu się w celu napominania tych opatów, którzy przekraczają regułę ${ }^{52}$. Synod diecezjalny $\mathrm{z}$ Auxerre, który zgromadził się w bliżej nam nieznanym roku, a który jednak musimy umieścić w latach 561-605, uściśla, iż opaci muszą udawać się corocznie dnia 1 listopada na synod diecezjalny ${ }^{53}$. Uczestnictwo opatów w synodach nie jest jednak czymś zupełnie nowym. Także bowiem wcześniej niektórzy opaci bywali na synodach przedstawicielami swych biskupów, a ich podpisy znajdują się w aktach synodalnych ${ }^{54}$.

${ }^{49}$ Por. Concilium Arelatense (29 VI 554), can. 3, CCL 148 A, 171: „Ut abbatibus longius a monastherio vagari sine episcopi sui permissione non liceat. Quod si fecerit, iuxta antiquos canones ab episcopo suo regulariter corrigatur".

${ }^{50}$ Por. Concilium Turonense (18 XI 567), can. 7, CCL 148 A, 178: „Ut episcopus nec abbatem nec archipresbyterum sine omnium suorum cumpresbiterorum et abbatum concilio de loco suo praesumat eiecere neque per premium alium ordinare nisi facto concilio tam abbatum quam presbyterorum suorum. Quem culpa aut negligentia eicit, cum omnium presbiterorum suorum concilio refutetur".

${ }^{51}$ Por. Concilium Aurelianense (7 V 538), can. 26 (23), CCL 148 A, 124: „Abbatibus, presbyteris citirisque ministris de rebus ecclesiasticis vel sacro ministerio alienare vel oblegare absque permisso et subscriptione episcopi sui nil liceat. Quod qui praesumserit, regradetur cummunione concessa et, quod taemere praesumtum aut alienatum est, ordenatione episcopi revocetur"; zob. także Concilium Aurelianense (14 V 541), can. 11, CCL 148 A, 134-135: „Si quid abbatibus aut sacris monastheriis aut parrociis pro Dei fuerit contemplatione conlatum, in sua proprietate hoc abbates presbyteri minime revocabunt nec alienare rem cunctis fratribus debitam quacumque occasione praesumant. Quibus si fuerit inpositum, ut constituta convellant, non aliter ualeat, nisi fuerit sui episcopi suscripsione firmatum".

52 Por. Concilium Aurelianense (14 V 541), can. 19, CCL 148 A, 10: „Abbates pro humilitate religionis in episcoporum potestate consistant et, si quid extra regolam fecerint, ab episcopis conrigantur; qui semel in anno, in loco ubi episcopus elegerit, accepta uocatione conveniant".

${ }_{53}$ Por. Synodus dioecesana Autissiodorensis (a. 561-605), can. 7, CCL 148 A, 266: ,[...] kalendis Novembris omnes abbates ad concilium conveniant".

${ }^{54}$ Por. np. Concilium Arelatense in causa Fausti (a. 449-461), CCL 148, 133-134; Concilium Carthaginense (6 II 525), CCL 149, 273-276; Concilium Massiliense (26 V 533), subscriptio, CCL 148 A, 86: „Valentinus abba directus a domno meo Fylagrio [= biskup Cavaillon, w prowincji 
2. Na Półwyspie Iberyjskim. Doroczne uczestnictwo opatów w synodach diecezjalnych potwierdził także synod prowincjalny z miejscowości Huesca w Hiszpanii. Odbył się on w 598 roku. Synod ten uazsadnia swe postanowienie troską o moralne postępowanie i o zachowywanie reguł kościelnych ${ }^{55}$. Nie wiemy, kto uczestniczył w tym zgromadzeniu prawodawczym. Wiemy jedynie, iż synod ten zgromadził się w trzynastym roku panowania króla Rekareda i że wydał dwa kanony, które później zostały potwierdzone przez synod w Tarrasie z 614 roku. Prawa te nakładają na biskupów obowiązek czuwania nad moralnością duchownych i zwoływania co roku synodu diecezjalnego ${ }^{56}$.

\section{ZAKŁADANIE NOWYCH KLASZTORÓW}

Odnośnie do zakładania nowych klasztorów, wypowiadają się jedynie trzy synody Galii. Pierwszy przepis w tym względzie został wydany przez synod w Agde dnia 10 września 506 roku; postanawia on, iż nowy klasztor może powstać tylko za pozwoleniem biskupa ${ }^{57}$. Przepis ten potwierdzi także synod w Orleanie z dnia 10 lipca 511 roku. Według niego żaden mnich, opuszczając swój klasztor pod wpływem próżnej chwały, nie może zbudować sobie nowej celi bez pozwolenia biskupa i bez aprobaty własnego opata ${ }^{58}$. Przepis ten został oczywiście wydany także po to, by ukrócić wałęsanie się mnichów. Ostatnie prawo w tym względzie wydał synod w Épaone z dnia 15 września 517 roku.

Arles] consensi et subscripsi"; Concilium Aurelianense (14 V 541), subscriptio [ex codicibus: K T IN ( $K=$ Coloniensis 212, a. 590-604, f. 94; $T=$ Tolosanus 364, ante annos 666-667, f. 75 v; $I=$ Albigensis 147, s. IX, f. 104; $N$ = Vaticanus Palatinus Latinus 574, s. VIII ex., f. 75 v)], CCL 148 A, 144: „[...] Amphilocius abba directus \{in $N$ : directus] missus\} a domno meo Amelio episcopo de Parisius [= in provincia ecclesiastica Senonensi] subscripsi" [i codici: $R$ H A B $(R=$ Berolinensis Phillips 1743, s. VIII, f. 149; $H=$ Berolinensis Latinus 435, s. VIII-IX, f. 143 v; $A=$ Parisiensis Latinus 3846, s. IX, f. $150 \mathrm{v} ; B=$ Vaticanus Latinus 3827 , s. IX-X, f. 101 v) zawierają tylko podpisy biskupów, por. CCL 148 A, 145-146]; Concilium Aurelianense (28 X 549), subscriptio, CCL 148 A, 160-161: „,...]. Optatus abbas directus a domno meo Praetextato episcopo ecclesiae Cabellicae $[=$ in provincia ecclesiastica Arelatensi] subscripsi. [...]. Sapaudus abbas directus a domno meo Albino episcopo ecclesiae Andicavensis [= in provincia ecclesiastica Turonensi] subscripsi”.

55 Por. Concilium Oscense (a. 598), can. 1, Mansi X 481: ,[...] hoc synodus sancta fieri elegit, ut annuis vicibus unusquisque nostrum omnes abbates monasteriorum, vel presbyteros, vel diaconos suae dioecesis ad locum, ubi episcopus elegerit, congregare praecipiat: et omnibus regulam demonstret ducendi vitas, cunctosque sub ecclesiasticis regulis adesse praemoneat: quosque etiam parcimoniae et sobrietatis, atque veridicae castimoniae, honestorum virorum testimonio fama commendet".

56 Odnośnie do tego synodu, por. P. de Luis, Huesca, DPAC II 1734.

57 Por. Concilium Agathense (10 IX 506), can. 27, CCL 148, 205: „Monasterium novum nisi episcopo aut permittente aut probante nullus incipere aut fundare praesumat".

58 Por. Concilium Aurelianense (10 VII 511), can. 22, CCL 148, 11: „Nullus monachus congregatione monasterii derelicta ambitionis et vanitatis inpulso cella construere sene episcopi permissione vel abbatis sui voluntate praesumat". 
Powtarza ono w skróconej postaci przepis poprzedniego synodu i wskazuje na biskupa jako na jedyną osobę, która może pozwolić na założenie nowego klasztoru $^{59}$.

\section{MIEJSCE ZAMIESZKANIA MNICHÓW}

Synody Galii potwierdzają, iż mnisi mają mieszkać w klasztorach pod nadzorem i opieką opata. Synod w Vannes, który odbył się w bliżej nam nieznanym roku, a który jednak trzeba umieścić w latach 461-491, postanawia, iż mnich nie może żyć w celi oddzielonej od innych współbraci. Może się to dokonać jedynie wówczas, gdy zakonnik osiągnie doskonałość, względnie wtedy, gdy jest chory lub słaby. Także i w tym jednak przypadku owa oddzielna cela musi znajdować się wewnątrz murów klasztoru, a sam mnich powinien nadal podlegać całkowicie władzy i opiece opata ${ }^{60}$. Kanon ten dosłownie powtórzy 10 września 506 r. synod w Agde ${ }^{61}$.

Synod wreszcie z Tours z dnia 18 listopada 567 r. uściśla, w jaki sposób mają mieszkać i spać mnisi. Nie wolno im spać z nikim w jednym i tym samym łóżku, ani też dzielić z innymi osobami wspólnej celi. Wszyscy powinni spać i mieszkać we wspólnej schola, pozostając pod nadzorem opata lub przeora ${ }^{62}$.

${ }^{59}$ Por. Concilium Epaonense (15 IX 517), can. 10, CCL 148 A, 26: „Cellas novas aut congregatiunculas monachorum absque episcopi notitia prohebemus instrui".

${ }^{60}$ Por. Concilium Veneticum (a. 461-491), can. 7, CCL 148, 153: „Servandum quoque de monachis, ne eis ad solitarias cellulas liceat a congregatione discedere, nisi forte probatis post emeritos labores aut propter infirmitatis necessitatem asperior ab abbatibus regula remittatur. Quod ita demum fiet, ut intra monasterii septa manentes, tamen sub abbatis potestate separatas habere cellulas permittantur"; zob. także Concilium Aurelianense (10 VII 511), can. 19, CCL 148 A, 10: „[...]. Monachi autem abbatibus omni se oboedientiae devotione subitiant”.

${ }^{61}$ Por. Concilium Agathense (10 IX 506), can. 38, CCL 148, 209: „Servandum quoque de monachis ne eis ad solitarias cellulas liceat a congregatione discere, nisi forte probatis, post emeritos labores, aut propter infirmitatis necessitatem asperior ab abbatibus regula remittatur: quod ita demum fiet, ut intra eadem monasterii septa manentes, tamen sub abbatis potestate separatas habere cellulas permittantur".

62 Por. Concilium Turonense (18 XI 567), can. 15 (14), CCL 148 A, 181: „Et ne occasio famam laceret honestatis, quia aliqui laici, dum diversa perpetrant adulteria, hoc, quod de se sciunt, in aliis suspicantur, sicut ait Senica: pessimum in eum vitium esse, qui in id, quod insanit, ceteros putat furere, ut et ipsis putantibus aut certe estimantibus locus amputetur, nullus sacerdotum ac monachorum colligere alium in lecto suo praesumat nec liceat monachis cellas habere communis, ubi aut bini maneant aut peculiarea reponi possint, sed scola laborem communi construatur, ubi omnes iaceant aut abbate aut praeposito imminentem, ut, dum duo vel tres uicissim et legunt et excubant, alii consolentur, ut non solum sit custodia corporum, sed et surgat pro lectione assidua profectus animarum". 


\section{DAROWIZNY}

W prawodawstwie kościelnym Galii znajdujemy cztery kanony, które ustalają przepisy dotyczące darowizn na korzyść mnichów. Synod w Orleanie z dnia 10 lipca 511 r. uchwala, iż każda własność ziemska udzielona duchownym lub mnichom przez biskupa, musi być zawsze zwrócona Kościołowi, nawet wówczas, gdyby upłynęło wiele czasu od początku jej użytkowania, czy nawet wówczas, gdyby prawa świeckie postanawiały w tym względzie coś innego ${ }^{63}$. Prawodawca nawiązuje tu niewątpliwie do Codex Theodosianus ${ }^{64}$.

Inny kanon, wydany przez tenże synod, mówi o darowiznach sensu stricto i postanawia, iż żaden członek duchowieństwa, opat, czy inny zakonnik nie może bez pozwolenia biskupa udać się do króla pro petendis beneficiis, to znaczy, by prosić o darowizny, z których można czerpać korzyści z ich użytkowania. Tym, którzy nie będą przestrzegali tego prawa, grozi kara klątwy do chwili zadośćuczynienia za przestępstwo poprzez pokutę, którą w odpowiedniej mierze ma wyznaczyć biskup ${ }^{65}$.

Synod w Agde z dnia 10 września 506 r. zakazuje opatom uwalniania niewolników podarowanych mnichom ${ }^{66}$. Przepis ten zostanie przejęty przez synod w Épaone z dnia 15 września 517 roku. Synod ten uważa ponadto za rzecz niesprawiedliwą pozbawiania mnichów, którzy codziennie muszą obrabiać pola, tego rodzaju pomocy ${ }^{67}$.

Ostatni tego rodzaju kanon został wydany przez synod w Orleanie dnia 14 maja 541 roku. Synod ten zgromadził czterech metropolitów, jednego kapłana jako wysłannika innego metropolity, trzydziestu ośmiu biskupów, jedne-

${ }^{63}$ Por. Concilium Aurelianense (10 VII 511), can. 23, CCL 148 A, 11: „Si episcopus humanitatis intuitu vineolas et terrulas clericis vel monachis praesteterit excolendas vel pro tempore tenendas, etiam si longa transisse annorum spatia conprobentur, nullum ecclesia praeiudicium patiatur nec saeculari lege praescriptio, quae ecclesiae aliquid inpediat, opponatur".

${ }^{64}$ Por. Codex Theodosianus IV 14, 1: „Imp. theodos. a. asclepiodoto pf. p. sicut in rem speciales, ita ad universitatem ac personales actiones ultra triginta annorum spatium minime protendantur. Sed si qua res vel ius aliquod postuletur, vel persona qualicumque actione vel persecutione pulsetur, nihilominus erit agenti triginta annorum praescriptio metuenda: eodem etiam in eius valente persona, qui pignus vel hypothecam non a suo debitore, sed ab alio possidente nititur vindicare. nam petitio finium regundorum in eo scilicet, quo nunc est, iure durabit".

${ }^{65}$ Por. Concilium Aurelianense (10 VII 511), can. 7, CCL 148 A, 7: ,Abbatibus, presbyteris omnique clero vel in religionis professione viventibus sine discussione vel commendatione episcoporum pro petendis beneficiis ad domnos venire non liceat. Quod si quisqui praesumserit, tamdiu loci sui honore et communione priuetur, donec per poenitentiam plenam eius satisfactionem sacerdos accipiat”.

${ }^{66}$ Por. Concilium Agathense (10 IX 506), can. 9, CCL 148, 226: „Mancipia vero monachis donata ab abbate non liceat manumitti".

${ }^{67}$ Por. Concilium Epaonense (15 VII 517), can. 8, CCL 148 A, 26: „Mancipia vero monachis donata ab abbate non leceat manumitti; iniustum enim potamus, ut monachis cotidianum rorale opus facientebus servi eorum libertatis otio potiantur". 
go opata i dziesięciu kapłanów pochodzących z pięciu prowincji kościelnych i z czterech innych. Synod wydał 38 kanonów, z których ostatni jest zakończeniem. Kanon 27 wspomina synod w Épaone z 517 r. i synod z Orleanu z 538 r., a kanony 2, 9, 17, 18 i 30 odwołują się ogólnie do wcześniejszych praw. Prawa wydane przez synod dotyczą między innymi duchownych, dóbr materialnych Kościoła i Wielkiego Postu ${ }^{68}$.

Co się tyczy darowizn, synod ten uściśla, iż jakikolwiek dar złożony dla kultu Bożego opatom i klasztorom nie może być uważany za osobistą własność, lecz należy do całej wspólnoty mniszej. Z tego też powodu nie można go alienować. Tak czy inaczej, w spornych sprawach należy się w tym wypadku zwracać do miejscowego biskupa ${ }^{69}$.

\section{KLASZTOR JAKO WIĘZIENIE - MIEJSCE, W KTÓRYM MOŻNA ODPOKUTOWAĆ ZA WINĘ}

Od początku VI wieku klasztory zaczęły stawać się także miejscami, w których przestępca (również osoba świecka) mógł odpokutować za winę, czy nawet schronić się przez karą śmierci. Najstarsze wiadomości w tym względzie pochodzą z Galii. W aktach bowiem synodu w Épaone z dnia 15 września 517 r. czytamy, że - jeśli diakon lub prezbiter popełni jakieś ciężkie przewinienie - musi zostać zamknięty w klasztorze, w którym jednak - aczkolwiek pozbawiony przywilejów związanych ze swym stanem duchownym - może do końca życia przyjmować Komunię Świętą ${ }^{70}$.

Taki sposób postępowania szybko się rozpowszechnił. Mówi o nim także synod w Lyonie, który odbył się w bliżej nam nieznanym czasie, a który trzeba umieścić w latach 518-523 $3^{71}$, a więc krótko po synodzie w Épaone ${ }^{72}$, oraz synod

${ }^{68}$ Odnośnie do tego synodu, por. Navarra, Merovingi (concili), DPAC II 2228; Limmer, Konzilien und Synoden im spätantiken Gallien, s. 225-233.

${ }^{69}$ Por. Concilium Aurelianense (14 V 541), can. 11, CCL 148 A, 134-135: , Si quid abbatibus aut sacris monastheriis aut parrociis pro Dei fuerit contemplatione conlatum, in sua proprietate hoc abbates presbyteri minime revocabunt nec alienare rem cunctis fratribus debitam quacumque occasione praesumant. Quibus si fuerit inpositum, ut constituta convellant, non aliter ualeat, nisi fuerit sui episcopi suscripsione firmatum".

${ }^{70}$ Por. Concilium Epaonense (15 IX 517), can. 22, CCL 148 A, 29-30: „Si diaconus aut presbyter crimen capitale conmiserit, ab officii honore dispositus in monasterio retrudatur, ibi tantummodo quamdiu uixerit cummunione sumenda".

71 Por. Concilium Lugdunense (a. 518-523), can. 4 (6), CCL 148 A, 41: „Domni quoque gloriosissimi regis sententia secuti id temperamenti praestitemus, ut Stephano praedicto vel Palladiae usque ad orationem plebis, quae post evangelia legitur, orandi in locis sanctis spatium praestarimus". Pod aktami tegoż synodu nie widnieje jednak podpis metropolity Lyonu - Wiwencjola, gdyż prawdopodobniej nie zgadzał się on z postanowieniami pozostałych ojców synodalnych. Nie spotykamy także podpisu Florencjusza - biskupa Orange lub Tricastiny, która należała do tej samej 
w Marsylii z dnia 26 maja 533 r. (był to pierwszy synod odbyty w tym mieście, a przewodniczył mu św. Cezary z Arles ${ }^{73}$ ). Ten ostatni synod posłał biskupa z Riez - Kontumelioza - do klasztoru na odbycie kary i zadośćuczynienie za grzechy. Biskupa tego oskarżono bowiem o trwonienie dóbr kościelnych i popełnianie grzechów cielesnych ${ }^{74}$.

Ten synod w Lyonie odbył się po śmierci Awita z Vienne, która nastąpiła 5 lutego 518 roku. Miał on jednak miejsce dopiero po roku 523. To zgromadzenie prawodawcze, któremu przewodniczył metropolita Lyonu - Wiwencjol, zajęło się głównie przypadkiem kazirodztwa, którego dopuścił się Stefan - minister skarbu królestwa Burgundii. Po śmierci żony ożenił się on bowiem powtórnie z siostrą Palladią. Dwaj metropolici obecni na synodzie - Wiwencjol z Lyonu i Julian z Vienne - oraz dziewięciu biskupów wydali w tej sprawie cztery kanony. Na synodzie odczuwało się bardzo silne napięcie pomiędzy królem Zygmuntem, który popierał swego ministra, a ojcami synodalnymi. Orzeczenie synodu łagodzi karę publicznej pokuty, którą kazirodczy Stefan i Palladia powinni byli odbyć. Synod postanawia bowiem, iż winowajcy, aczkolwiek skazani, mają zostać na nowo włączeni do Kościoła po odczytaniu Ewangelii, podczas odmawiania modlitwy wiernych ${ }^{75}$. Po tym wyroku synodu w Marsylii z dnia 26 maja 533 r. papież Jan II (533-535) w 534 r. postanowił, wysyłając trzy listy $^{76}$, że biskup Kontumelioz ma nie tylko zostać zamknięty w klasztorze (in Casensi monasterio), lecz także złożony z urzędu. Następca Jana II - papież

metropolii. Kodeks ponadto $R$ (Berolinensis Phillipps 1743, wiek VIII, f. 131) nie zawiera także podpisu innego metropolity - Juliana z Vienne.

${ }^{72}$ Por. Concilium Lugdunense (a. 518-523), can. 1 (3), CCL 148 A, 39: „Quod si se rex praecellentissimus ab ecclesiae vel sacerdotum comunione ultra suspenderit, locum ei dantes ad sanctae matris gremium veniendi, sancti antistetes se in monasteriis absque ulla dilatione, prout cuique fuerit oportunum, recipiant, donec pacem dominus integram ad caritatis plenitudinem conservandam sanctorum flexus praecibus restituere pro sua potensia vel pietate dignetur, ita ut non unus quicunque prius de monasterio, in quo elegerit habitare, discedat, quam cunctis generaliter fratribus fuerit pax promissa vel reddita".

${ }^{73}$ Odnośnie do tego synodu, por. Navarra, Merovingi (concili), DPAC II 2228.

74 Por. Concilium Massiliense (26 V 533), CCL 148 A, 85: „Cum ad civitatem assiliensem propter requirenda et discutienda ea, quae de fratre nostro Contumilioso episcopo fuerant devulgata, sacerdotes Domini convenissint, residentibus sanctis episcopis cum grandi diligentia discussis omnibus secundum quod gesta, quae nobis praesentibus facta sunt, continent, multa turpia et inhonesta supra dictus Contumiliosus conuictus ore proprio se confessus est perpetrasse, ita ut non solum revincere testis non potuerit, sed etiam publice in conventu episcoporum et laicorum, qui interfuerant, in terram se proiciens clamaverit se graviter in Deum et in ordine pontificali peccasse. Pro qua re propter disciplinam catholicae religionis utile ac salubre omnibus uisum est, ut supra dictus Contumeliosus in Casensi monasterio ad agendam paenitentiam vel ad expianda ea, quae ammiserat, mitteritur; quam rem stodio paenitendi et ipse libenter amplexus est".

${ }^{75}$ Odnośnie do tego synodu, por. Navarra, Merovingi (concili), DPAC II 2228.

${ }^{76}$ Por. Ioannis II papae epistulae I-III, CCL 148A, 86-87. 
Agapit I (535-536), do którego odwołał się Kontumelioz, zlecił ponowne rozpatrzenie całej tej sprawy trybunałowi sądowemu ${ }^{77}$.

Także synod w Orleanie z dnia 7 maja 538 r. postanawia, by zamykać w klasztorze tych honorati clerici (czyli: duchownych od subdiakona wzwyż $\dot{z}^{78}$ ), którzy dopuścili się cudzołóstwa. Chociaż będą oni zawieszeni w wykonywaniu właściwych im posług kościelnych i zamknięci w klasztorze przez całe życie, będą jednak mogli przyjmować w nim Komunię Świętą ${ }^{79}$.

W klasztorze można także zamykać w celu odbycia kary kobiety świeckie. Drugi bowiem synod w Mâcon z roku 585 (być może odbył się on 23 października tegoż roku ${ }^{80}$ ) postanawia, iż żony subdiakonów, egzorcystów i akolitów po śmierci swych mężów nie mogą wyjść powtórnie za mąż. Gdyby jednak mimo wszystko zawarły małżeństwo, mają zostać oddzielone od męża i dożywotnio zamknięte w klasztorze żeńskim ${ }^{81}$. W synodzie tym uczestniczyło siedmiu metropolitów i dwóch delegatów, czterdziestu dziewięciu biskupów oraz sześciu wysłanników pochodzących z ośmiu ich prowincji kościelnych i z jakiejś innej prowincji. Uczestniczyło w nim także trzech biskupów nie zasiadających na żadnej stolicy. Pomimo tak licznego uczestnictwa ojców synodalnych nie możemy uznać tego zgromadzenia prawodawczego za synod narodowy, gdyż nie byli na nim obecni biskupi z królestwa Childeberta II. Synod wydał dwadzieścia kanonów dotyczących prawa publicznego Kościoła, kazirodztwa i życia liturgiczno-sakramentalnego. Kanony 5, 6, 8, 9, 15, 17, 18 oraz 20 odwołują się do wcześniejszych praw synodalnych. Według Kroniki Pseudo-Fredegariu$\mathrm{sza}^{82}$, w tymże dwudziestym czwartym roku panowania król Guntran „,senodum 40 episcoporum fieri precepit”. Prawdopodobnie chodzi tu właśnie o tenże synod w Mâcon ${ }^{83}$.

77 Por. Epistula Agapiti I papae, CCL 148 A, 96-97, którą dnia 18 lipca 553 r. przesłał św. Cezaremu z Arles.

${ }^{78}$ Por. Concilium Aurelianense (7 V 538), can. 2, CCL 148 A, 114: „Ut nullus clericorum a subdiacono et supra, qui uxores in proposito suo adcipere inhibentur, propriae, si forte iam habeat, misciatur uxori".

79 Por. Concilium Aurelianense (7 V 538), can. 8, CCL 148 A, 117: „, De adulteriis autem honoratorum clericorum id observandum est, ut, si quis adulterasse aut confessus fuerit vel conuictus, depositus ab officio communione concessa in monasterio tot vitae suae tempore retrudatur"; zob. także Limmer, Konzilien und Synoden im spätantiken Gallien, s. 448, przypis 1471.

${ }^{80}$ Nie znamy dokładnie ani dnia, ani miesiąca, w których zgromadził się ten synod. Możemy je tylko w przybliżeniu ustalić na podstawie jednego z dzieł św. Grzegorza z Tours (por. Historia Francorum VII 7).

81 Por. Concilium Maticonense secundum (23 X? 585), can. 16, CCL 148 A, 246: ,Ilud quoque rectum nobis uisum est disponere, ut, quae uxor subdiaconi vel exorcistae vel acoliti fuerat, mortuo illo secundo se non audeat sotiare matrimonio. Quod si feceret, separetur et in coenubiis puellarum Dei tradatur et ibi usque ad exitum vitae suae permaneat".

${ }^{82}$ Por. Ps. Fredegarii Chronica IV 1.

83 Odnośnie do synodu w Mâcon, por. C. de Clercq, Concilium Matisconense CCL 148A, 237; Navarra, Merovingi (concili), DPAC II 2230. 
Nie zawsze zamknięcie przestępcy w klasztorze było dla niego okresem surowej pokuty! Kanon bowiem VI synodu w Narbonie z dnia 1 listopada 589 r. postanawia, że opat klasztoru, w którym zamknięty jest jakiś przestęp$\mathrm{ca}$, powinien obchodzić się z nim zgodnie z tym, co postanowił biskup. Przepis ten przywołuje do porządku tych opatów, którzy przekształcali więzienie przestępców w przyjemne dla nich miejsce pobytu. Względem opatów, którzy nie będą przestrzegali tego postanowienia, kanon postanawia jako karę zawieszenie ich w wykonywaniu władzy klasztornej ${ }^{84}$. Co się tyczy tegoż synodu, możemy powiedzieć, iż - w zgodzie z III synodem w Toledo, który odbył się w maju 589 r. w obecności króla Wizygotów Rekareda, a który postanowił, że w każdej prowincji kościelnej królestwa ma zebrać się raz w roku synod prowincjalny dnia 1 listopada - tenże synod prowincjalny w Narbonie odbył się pod przewodnictwem metropolity Migecjusza - biskupa Narbony. Ogłoszono na nim piętnaście kanonów dotyczących duchownych, liturgii (skrócono psalmodię i po każdym psalmie dodano śpiew Gloria Patri), oraz czarów. Kanony 3, 5, 6 oraz 13, odwołują się wyraźnie do postanowień synodu w Toledo ${ }^{85}$.

Synod wreszcie w Auxerre, który zgromadził się w bliżej nam nieznanym czasie, a który możemy umieścić w latach 561-605, przewiduje karne zamykanie w klasztorze nawet samych mnichów. Postanawia bowiem, że opaci, którzy pozwalają kobietom wchodzić do klasztoru, względnie urządzają w klasztorze jakieś huczne zabawy, mają zostać zamknięci na trzy miesiące w innym klasztorze i przebywać w nim o chlebie i wodzie ${ }^{86}$.

$* * *$

Z prawodawstwa kościelnego badanych przez nas wieków na obszarach łacińskich basenu Morza Śródziemnego można wyciągnąć ciekawe wnioski co do zasadniczych zagadnień dotyczących monastycyzmu i życia mnichów. Zagadnienia te są zaś wielorakie. Na pierwsze miejsce wysuwają się tu przepisy dotyczące możliwości przyjęcia przez nich święceń kapłańskich, czy przestrzegania stabilitas loci (w przypadku kobiet sprawy te nie były nawet brane pod uwagę), zadań opata, oraz zakładania nowych wspólnot klasztornych.

${ }^{84}$ Por. Concilium Narbonense (1 XI 589), can. 6, CCL 148 A, 255: „Secundum concilia priscorum orthodoxorum decrebit fraternitas, ut quicumque fuerit culpavilis inventus clericus aut honoratus de civitate, et ad monasterium fuerit deputatus, sic abba qui est predictus cum illo qui dirigitur agat, sicut ab episcopo manifesta correctione fuerit ordinatus. Aliter si abba facere elegerit, pro correctionem tempus aliquod suspendatur; quia ob ac causa dirigitur, ut emendet, non ut passim ferculis diversis saturetur".

85 Odnośnie do tego synodu, por. Navarra, Merovingi (concili), DPAC II 2230.

${ }^{86}$ Por. Synodus dioecesana Autissiodorensis (a. 561-605), can. 26, CCL 148 A, 268: „Quod si quis abbas mulierem in monasterio suo ingredi permiserit aut festivitates aliquas ibi spectare praeceperit, tribus mensibus in alio monasterio retrudatur panem et aquam contentus". 
Także te ostatnie zagadnienia nie pojawiają się w prawodawstwie dotyczącym ascetek, co jest być może znakiem, że ich kierownictwem zajmowali się bezpośrednio mnisi, od których one ściśle zależały.

Co się tyczy ascetek, nie spotykamy także norm zajmujących się prawowiernością ich wiary, jak jest w przypadku mnichów, gdyż ci ostatni brali częstokroć udział w dysputach teologicznych owych wieków zarówno na Wschodzie, jak i na Zachodzie.

Trzeba także podkreślić, iż prawodawstwo kościelne zajmowało się również cnotami mnichów, ich pokorą i postami. Na podstawie tego jasno widać, że Kościół cenił i dbał o zachowanie nienaruszonym charyzmatu mniszego, a szczególnie tego, który osobliwie go cechuje: pokory i umartwienia.

Typowo łacińskim jest także w ówczesnym prawodawstwie zagadnienie dotyczące dóbr materialnych klasztorów, donacji, czy postrzegania klasztoru jako miejsca zastępczego względem więzienia dla przestępców, a to oczywiście ze względu na surowe i zamknięte życie mnichów. Szczegół ten świadczy zgodnie z wszystkimi źródłami hagiograficznymi i ascetycznymi, że monastycyzm łaciński na ziemiach basenu Morza Śródziemnego przejął radykalizm ewangeliczny mnichów wschodnich i potrafił dostosować go do własnego sposobu myślenia.

Ostatnią wreszcie cechą, która wyróżnia monastycyzm łaciński, jest jego składnik intelektualny, który odciął się w tym względzie od ascetycznej dychotomii wschodniej. Na pytanie: „kultura czy świętość?”, które z zasady spotykamy u mnichów wschodnich, monastycyzm łaciński odpowiedział: „,kultura i świętość", co miało od tej pory cechować antiquitas Christiana latina. Monastycyzm benedyktyński stanie się tego doskonałym przykładem. Zaszczepiając mocno chrześcijańskie korzenie na kontynencie europejskim, stanie się on wielkim spadkobiercą także kultury starożytności chrześcijańskiej, pielęgnując ją w nowych warunkach Średniowiecza.

\title{
LA PIÙ ANTICA LEGISLAZIONE DELLA CHIESA LATINA NEL MEDITERRANEO RIGUARDANTE IL MONACHESIMO MASCHILE
}

\author{
(Riassunto)
}

L'articolo prende in esame il monachesimo latino maschile nel Mediterraneo perlustrando, per quanto concerne i secoli IV-VI, la legislazione ecclesiastica che di regione in regione ne ha regolato vita e modalità d'essere. Vengono analizzati gli atti conciliari del Mediterraneo latino che riguardano la vita religiosa maschile a comin- 
ciare dagli stessi inizi della legislazione ecclesiastica fino all'arrivo degli albori dell'Alto Medioevo. L'articolo esamina tutti i canoni concernenti gli asceti che furono promulgati dalla Chiesa dell'Africa, della Gallia, della Penisola Iberica e dell'Italia.

I concili come tali manifestano molto bene la vita della Chiesa, rispecchiando i diversi problemi e le situazioni (spesso difficili) che influirono sulla promulgazione degli stessi canoni, fornendo, in tal modo, un prezioso quadro sia storico che, insieme, teologico-spirituale-giuridico. In seno ad esso, però, molto importante pare sia quello che riguarda il monachesimo delle origini, dal momento che questo movimento carismatico-spirituale così importante per la vita della Chiesa nasce proprio in quel periodo e in esso trova le sue fondamenta giuridiche, che assicurarono il suo instancabile cammino verso la casa del Padre, insieme e a capo del popolo di Dio quale sua guida carismatico-spirituale.

Vengono presentati i canoni riguardanti i monaci, e ciò seguendo l'ordine cronologico della loro promulgazione. Viene presentata dapprima la legislazione africana, successivamente quella della Gallia e della Penisola Iberica. Pochissime, invece, sono le leggi della Chiesa di Italia.

È attraverso la lettura delle tematiche entrate nelle normative allora vigenti, e talvolta sensibili di differenze da luogo a luogo, che si comprendono problemi, usanze e dinamiche di un fenomeno il quale si è umilmente imposto nel tessuto della Chiesa e delle istituzioni. Ciò testimonia pure quanto sia sembrato essere stato ritenuto importante il salvaguardarne integrità e verità, e non solo il riconoscimento ufficiale. 